\title{
Partnership Model Study To Batik And Ulos Craftsmen \\ In Dealing With Global Competition
}

\author{
Sari Bulan Tambunan (Author) \\ Departement of Management \\ Faculty of Economics, \\ Medan Area University \\ Medan, Indonesia \\ Linda Lores (Co Author) \\ Departement of Management \\ Faculty of Economics, \\ Medan Area University \\ Medan, Indonesia
}

Linda_lores@ymail.com

Dhian Rosalina (Co Author)

Faculty of Economics, Samudra

University

Langsa, Indonesia

dhian.rosalina@yahoo.co.id
Abstract-Partnership is the series of processes that begin with knowing the potential partners, the advantages and weaknesses of his business, building strategies, implementation, monitoring and to evaluate until the target is achieved This research aimed to find the right partnership model For Craftsmen batik cloth and ulos in Medan

This type of research is research development (Resarch and Development) by using interactive analysis, Outcome in this research is development model with innovative and creative base. Respondents This research is a typical batik cloth craftsmen and ulos in North Sumatra in Medan City by involving relevant government agencies. Data collection technique with purposive sampling technique and FGD is used for model refinement, Based on the results of data collection, there are 30 business actors who pursue batik handicrafts typical of North Sumatra, while others amounted to twenty people engaged ulos cloth business.

The result of this study: The model described is as follows: Companies, Banking, Private sectors, Non-Governmental Organizations (NGOs), Universities in cooperation with the Government as a source of information on the existence of SMEs and Protectors, cooperate in a center called: SME's Promotion Produc Institution in charge of cooperation program between SMEs and Parties working together under the supervision of this center.

Keywords: Creative Economy, Interactive Analysis, SMEs Promotion Product Institution

\section{Introduction}

This research concerns the problems faced by Small, Medium Enterpises(SMEs) in the field of creative 
industries namely batik cloth and ulos craftsmen who become the pride of the people of North Sumatra. North Sumatra which has a local cultural heritage that potential to be developed and become a local identity for the city of Medan in particular and North Sumatra in general. Handicrafts such as Batik motifs typical North Sumatra and Batak ulos are one of the cultural heritages that can be developed and are one of the creative economy that focuses on the creation of goods and services by relying on expertise, talent, and creativity as intellectual property. SMEs's products are already in great demand by overseas including Japan, America, Netherlands, Germany and others.

Problem-based SMEs creative economy in general are human resources, capital, and mastery of modern technology [2]. Condition-based SME creative economy in North Sumatra at this time, judging from empowerment opportunities from time to time, from place to place, and from sector to sector does not indicate the magnitude of the expectations on the business group to support the growth of a sustainable economic system.

The problems of batik cloth and ulos craftmen above can be solved through the partnership program between MSMEs, between MSMEs and Big Enterprises, between SMEs with Cooperatives that aims to expand market share and business management more efficiently thus the UMKM will have the power to compete with the perpetrators other business. Efforts to increase the existence of MSMEs is through a partnership pattern, set out in Presidential Decree No. RI. 127 of 2001 on MSME and Partnership, stating that there is a need for a kind of business reserved for small businesses and open opportunities for the performance of medium or large enterprises under terms of partnership. Partnership is a partnership between small-scale enterprises and medium-sized enterprises or large enterprises with the fostering and development of medium-sized enterprises or large enterprises with due regard to the principle of mutual need, mutual strengthening and mutual benefit.business people

Partnership is the series of processes that begin with knowing potential partners, the positions of excellence and weakness of their business, start building strategies, implementing, monitoring, and evaluating until the target is achieved. Pattern of partnership between SMEs in Indonesia that has been standardized, according to Law no. 9 of 1995 concerning Small Business and Government Regulation no. 44, 1997 on partnership, consists of 5 (five) patterns, namely: (1). Inti Plasma, (2) .Subkontrak, (3). Dagang Umum, (4) .Keagenan, and (5). Waralaba

As in [23], Many micro, small and medium enterprises (MSMEs) fail to develop because they do not get certainty on the supply of input and output marketing. Financial institutions do not see in a comprehensive way the production chain such as processing, marketing as a series of businesses that operate in unity and capital can be returned. The involvement of input, process, output and market access to MSMEs is often not properly organized. The package of business development policies does not focus on the business units that are formed. Government efforts have not been 
optimal in developing partnership network in developing UMKM. Partnerships within the framework of business linkages are conducted through patterns appropriate to the type of business being partnered by being given the widest possible partnership opportunities to Small Businesses, by the Government and the business world

Effective partnership relationships motivate each individual partner to gain goals and safeguard their own interests. As in [21] However, the implications of the partnership relationship in the organization, certainly not apart from the problems [21]. Preliminary research results conclude the problems of MSME failure with partnerships that occur, among others: SME development agencies are usually bureaucrats / professionals, not entrepreneurs, the pattern is not comprehensive, truncated, generally training and not sustainable.

\section{Formulation of Research Problems}

Based on the background of this research problem it is necessary to create a model of partnership that supports the development of business actors batik and ulos, so the formulation of this research problem is: how the right partnership model to overcome the problems faced by batik cloth and ulos craftsmen in Medan City?

\section{Partnership Model of Micro, Small and Medium Enterprises}

The partnership model that has been implemented in Indonesia is as follows as in [24]: a. The core plasma partnership model is a partnership between SMEs and large enterprises as the core of fostering and developing SMEs that are in their position to provide land, production facilities, technical management and production management guidance, acquisition, mastery and technological improvements necessary for efficiency improvement and business productivity. In this case, large businesses have a social responsibility (corporate social responsibility) to foster and develop SMEs as business partners for the long term.

b. The subcontract partnership model is a partnership between SMEs and large enterprises, in which it produces the components required by large enterprises as part of its production. Subcontracting as a system that describes the relationship between large enterprises and SMEs, which the Big Enterprise as parent firm (parent firma) ordered to UMKM as subcontractor to do all or part of work (component) with full responsibility to parent company. In addition, in this partnership model large enterprise provides assistance in the form of opportunities for raw material acquisition, guidance and technical capability of production, technological mastery, and financing

c. Partnership Model The general trade linkage, is a partnership between SMEs and large enterprises, whereby large 
businesses marketing SMEs or SMEs produce the necessary needs of large entreprises as its partners. In this partnership model, large businesses market products or receive supplies from SMEs to meet the needs required by large enterprises.

d. The Agency Partnership Model is a partnership relationship between SMEs and large enterprises, in which SMEs are given special rights to market UB goods and services as its partners. The agency model is a partnership relationship, where the principal produces or owns something, while the other party (agent) acts as the party who runs the business and connects the product in question directly with the third party.

e. The franchise partnership model is a partnership relationship, in which the franchisor grants the right to use its licenses, trademarks and distribution channels to the franchisee with the assistance of management guidance. In this model, large businesses acting as franchisors provide guarantees proposed by MSMEs as franchise recipients to third parties

\section{Types of Research}

This research is a research development (research and development) in which researchers analyze the development model that will be applied to batik cloth and ulos craftsmen to improve the capacity building of craftsmen. This research involves several government agencies to improve the results of model development.

\section{Population and Sample}

The population in this research is craftsman of batik and ulos in Medan City. The sampling technique used is purposive sampling with the following criteria:

1. Batik and ulos crafts are typical of North Sumatra

2. Respondent is owner of craft business

3. Respondent's business specialization is batik and ulos (not a side job)

4. Long time work on batik and ulos at least 2 years

Determination of the target area of research is the area of Medan City, especially in Medan Tembung and Denai, while the craft of ulos obtained from the craftsmen built by Disperindag of North Sumatra and Medan City

\section{Data Collection Techniques}

This study uses primary data and secondary data, primary data obtained through Interview and Focus Group Discussion (FGD). The researcher interviewed the respondents of this research : the craftsman of batik and ulos in Medan City which is in accordance with the criteria set by the researcher, this research also held FGD to a number of government institutions in Medan City who are willing to provide information that support the improvement of batik industry development model and ulos . 
Secondary data in this research is the profile and the existence of craftsmen of batik and ulos crafts in North Sumatra, secondary data comes from the Department of Cooperatives and SMEs of North Sumatra and Medan, Industry and Trade, and from the National Craft Council of Medan (Dekranas).

\section{Constraints faced by artisans}

\section{a. Craftsman of Ulos}

Just like the common problems faced by other small and mediumsized businesses, ulos (partonun) craftsmen have some constraints in production activities. Some of the constraints can be spelled out in the following points:

\section{Marketing}

Ulos cloths have constraints in terms of pricing, ulos work using a traditional tool commonly called Gedogan to wool and silk fabrics into ulos ready to use manually takes the fastest completion time of three weeks. The duration of workmanship and skill required in ulos settlement make ulos price is quite expensive.

The lack of use of ulos is also a constraint, production is done continuously but the limited market makes ulos difficult to develop, according to the ulos cloth craftsmen identified with traditional ceremonial activities so that if no customary activities ulos is not used.

\section{Finance}

Financial constraints faced by ulos craftsmen, among others, caused by the demand for a little ulos cloth, with little demand to disrupt the finance of craftsmen because of lack of income.

\section{Equipment}

In the production process ulos still use manual techniques. There are two looms used are traditional looms and Non Weaving Machine.

Where looms are used operation manually so that the process of ulos manually can be reached in one month. According to craftsmen of Non-Machine Looms (ATBM) help ulos settling process faster manually, but the price is relatively expensive so not all craftsmen have ATBM. While the materials needed to make ulos cloth such as cotton, wool fabric, silk fabric, dye, bark, etc. are relatively easy to find.

\section{Labor}

Ulos work can not be done by anyone, ulos work requires a certain skill that requires the process, patience and thoroughness, given the complexity of ulos weaving manually, most ulos craftsmen get the expertise from generation to generation.

b. Craftsman of Batik Fabrics

\section{Marketing}

Marketing on batik cloth typical of North Sumatra is still limited, batik products still have not reached the national market. The craftsmen recognize most buyers of batik products North Sumatra are the government and private institutions in the surroundings of Medan. However, due to lack of promotion, the unique potential of North Sumatra batik is not popular nationally.

Equipment 
Constraints of equipment faced by many batik craftsmen of North Sumatra, this is because the raw materials of batik making are all produced from Java. Equipment such as canting and canting cap typical for batik work, the craftsmen have to make reservations from suppliers in Java, Solo exactly. While other tools such as white cotton cloth, pencil patterns, coloring materials and stoves can still be met from the city of Medan.

\section{Labor}

Skilled workers become obstacles when artisans receive many requests for batik cloth. Not many young people who pursue the craft Batik cloth typical of North Sumatra although economically profitable.

\section{Craftsman Partnership in the craft of Batik and Ulos}

Based on the observations, batik and ulos craftsman work together with government and private agencies in improving product quality and for business development. It shows the enthusiasm of the craftsmen to advance the cultural heritage of North Sumatra is quite high.

\section{Support of Government and Private Agencies to craftsmen}

Based on the results of interviews with the craftsmen, it is known that government and private agencies play a role in providing assistance. The forms of assistance from the agencies summarized in the interview are as follows:

\section{a. Equipment}

The ulos craftsmen in Samosir and surrounding areas get the help of Non-Machine Looms
(ATBM) which help the craftsmen working faster than traditional looms (gedogan). This assistance is obtained from Government and Private Institutions.Typical batik artisans of North Sumatra also get the help of capital tools such as canting and stamp motifs. received by batik craftsmen is still from government agencies only.

b. Training

Ulos craftsmen received training on the use of silk fabric with Non-Engine Weaving Equipment (ATBM) from agencies that provide capital equipment, but although the potential of silk ulos is large enough the potential of many artisans is reluctant to attend the training due to the high cost of silk thread and the difficulty level compared to the workmanship using wool cloth. Ulos craftsmen get product innovation training, where government agencies introduce diversified products made from ulos such as bags, shoes, and so forth. Thus expanding the use of ulos cloth in public spaces.

Batik craftsmen are also training creative batik making. Training to make motifs often obtained batik artisans from government agencies. Like ulos, batik craftsmen also get training in product diversification such as bags, shoes, trays, and so on with batik motifs of North Sumatra.

.c. Marketing

Both batik and ulos artisans get marketing support from government agencies by involving typical North Sumatra products to various exhibitions in Indonesia and abroad. Generally, the 
craftsmen have not mastered online marketing so that it takes training on e-commerce to improve batik and ulos craft market.

\section{d. Business Establishment}

There are craftsmen who are incorporated in the local government bank business, business support here is the provision of business credit assistance and training financial reports. But most artisans do not get or join this business.

\section{Pattern or Model Partnership For Batik and Ulos Craftsmen}

Based on the observation of the researcher to the artisans of batik and Ulos, there are some conclusions in making the partnership model that is expected from the craftsmen in the form of partnership that not only provide marketing, capital and raw materials but needed partners who help the craftsmen become an entrepreneur, the Government has supported the craftsmen by developing batik and ulos craftsmen with various activities and facilities given to craftsmen, but there are still unidentified craftsmen to be given the facility, this shows the need to be formed batik and ulos artisans community in the field which consists of all batik and ulos artisans in the city of terrain. The role of the successful craftsmen business is also expected to empower the builder of Batik and Ulos craftsmen who are still small operational.

Like companies that have CSR programs to the community, it is very helpful for batik and ulos craftsmen, there are some companies that provide aid only production equipment, working capital, training for labor and others. The assistance provided by the company has worked well, but such assistance should be provided along with continuous guidance until the craftsmen can become selfemployed entrepreneurs or entrepreneurial groups. Researchers create models that are expected to help empower and strengthen SMEs of batik and ulos in a model or partnership pattern: Government as the protector and policy maker of SMEs, private parties, corporations, communities, universities should work together to empower SMEs Batik and Ulos.

The model described is as follows: Companies, Banking, Private Parties, Non-Governmental Organizations (NGOs), Universities in cooperation with the Government as a source of information on the existence of SMEs and Protectors, cooperate in a center called: SME's Promotion Produc Institution in charge of cooperation program between SMEs and Parties working together under the supervision of this center. 


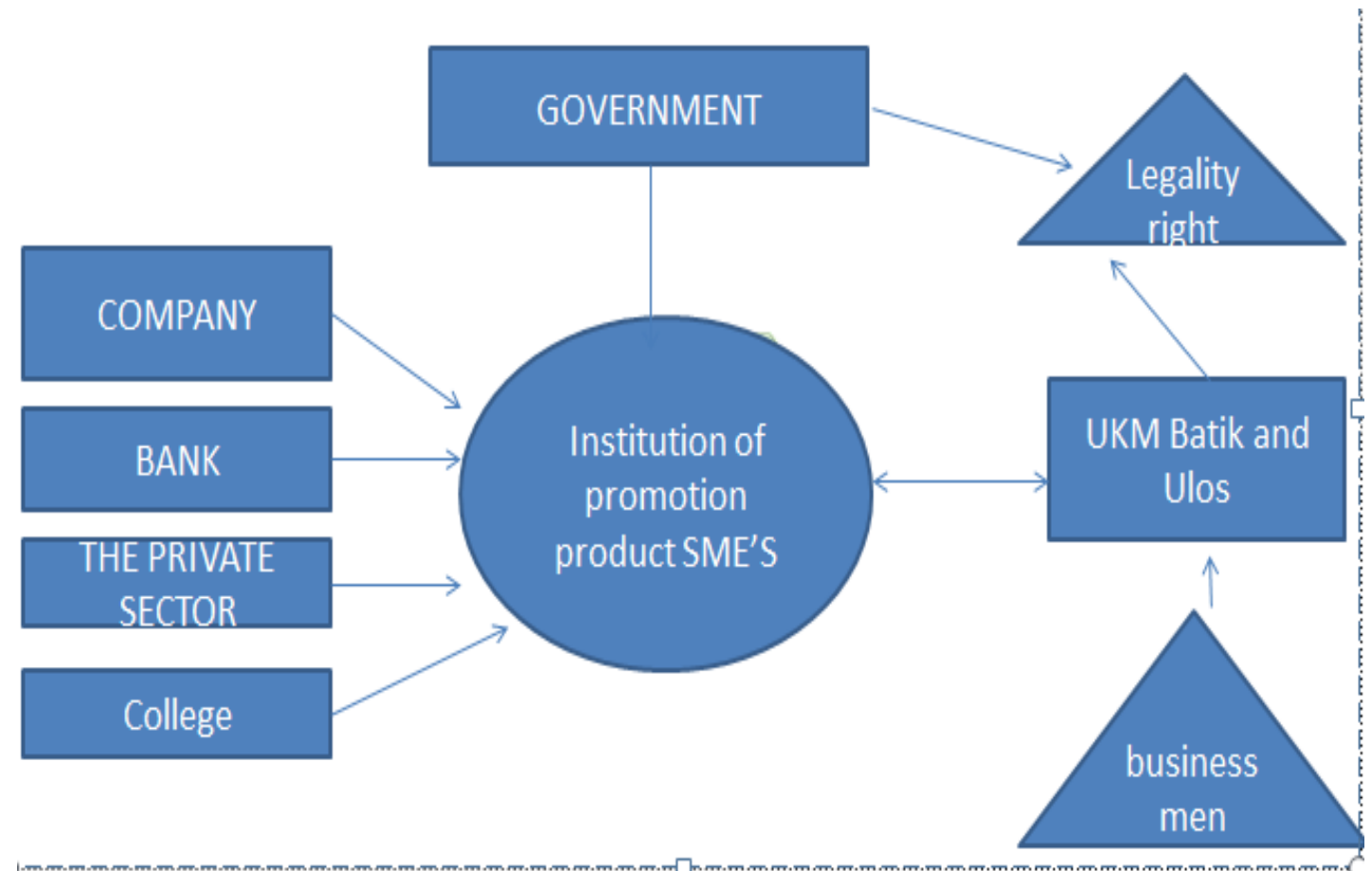

Figure 1

Partnership Model

Small business product promotion center acts as a liaison between big companies, banks, and universities in providing various contributions to increase the competitiveness of batik art craftsmen and ulos of North Sumatra. These contributions include:

\section{a. Marketing, by:}

1. Helping open network or market access;

2. Promote the products of craftsmen

3. Helping to identify the market and consumer behavior;

4. Helping to increase product quality and value-added packaging.

\section{b. Guidance and development of human} resources, by:

1. Education and training of product design and innovation

2. Comparative study;

3. Consultation or Assistance

\section{c. Capital:}

1. Provision of credit information

2. The mediator of the sources of financing;

3. Information and procedures for equity participation;

\section{d. Management:}

1. Proper financial management

2. To provide assistance to be copyright and trademark.

\section{e. Technology, by:}

1. Helping innovation and technology transfer;

2. Assist in the development of innovative product design; [23]

Contribution from parties who cooperate with small business product promotion center will be able to help 
improve the competitiveness of batik cloth and ulos typical of North Sumatera

Basically partnership is a reflection of the willingness of the party has excess resources to help other people who lack the resources, ie those who do require coaching. Therefore, in essence the pattern of such approach is a mirror or a form of a sense of concern to promote small business.

\section{Acknowledgment}

Craftsmen are looking for sustainable partnerships in skills, marketing and capital tool support. Skill enhancement is needed by craftsmen to innovate products and can be more productive to produce new products acceptable to the market. Marketing support is crucial for artisans since ulos is still synonymous with ceremonial ceremonies so partners are needed to introduce ulos more widely to public space in the form of diversification of products made from ulos, as well as batik fabrics North Sumatra also need to receive marketing training assistance either through the exhibition as well as on line to expand market reach. Support of capital tools will also be required by artisans considering the high cost of production equipment will be able to inhibit the craftsmen in meeting market demand

\section{Reference}

[1] Augustin Rina Herawati, Sistem Kemitraan Usaha Mikro Kecil Menengah (Umkm) - Usaha Besar
Dengan Pemodelan Systems

Archetype , Disertasi, UI, 2011

[2] Adiningsih, Adi. 2010. Regulasi

Dalam Revitalisasi Usaha

Kecil dan Menengah di

Indonesia.www.lfip.org

[3] Candiwan.2014. Analysis of ISO

27001 Implementation for

Entreprises and SMEs In

Indonesia. Proceeding of The

International Conference on

Cyber Crime Investigation and

Cyber Security, Kuala Lumpur

[4] Direktorat Peningkatan Peran

Kelembagaan Sosial

Masyarakat dan Kemitraan

Direktorat Jenderal

Pemberdayaan Sosial

Departemen Sosial RI,

Acuan Jaringan Kerjasama

Dunia Usaha Dalam

Pembangunan Kesejahteraan

Sosial, 2005

[5] Erfit. Analisis Kesetaraan

Dalam Kemitraan Pada

Agribisnis Hortikultura. Jurnal

Embrio. Volume 5, No.2. 2012

[6] Jingga, Freddy., Limantara,

Natalia. 2015. The

Development of Indonesia

Small Medium Enterprise 
(SME) Rating and Review

Portal. International Journal of

Multimedia and Ubiquitous

EngineeringI. Vol 10 (3)

pp. $211-218$

[7] Golibjon, Y. 2016. Innovation and SME Development:

Indonesian Experience in

Uzbekistan Context. Journal of

Entrepeneurship \&

Organization

Management.5(3)

[8] Indris, Sofyan.,Primiana, Ina.

2015. Internal and External

Environment Analysis The

Performance of Small and

Medium Industry in Indonesia.

International Journal of

Scientific and Technology

Research Volume. Vol 4. April

[9] Iqbal, Badar

Alam.,Rahman,Mohd. Nayer.,

2015. Contribution of

ASEAN-6 SMEs to Economics

Growth of ASEAN. Economic

World, Vol.3 No 11-12, pp

258-269 .Decemberminia, I

[10] Najib, Mukhamad, 2013.

Internal Sources of

Competitiveness In Samll and

Medium Indonesian Food

Processing Companies. ASEAN
Journal of Economics,

Management and Accounting 1

(1): 101-117. Juni

[11] Mohani, Abdul.,hasanah, Ismail., Mazlina, Mustafa.

2013. Indonesian Small

Medium Entreprises (SMEs)

and Perception on Halal Food

Certification. African Journal

of Bussiness Managhement.

Vol 7 (16).pp 1492-1500. 28

April

[12] Sulistyo, Heru., Adiatma,

Ardian. Model Optimalisasi

Kemitraan UKM (Usaha Kecil

Menengah) dan BUMN

Melalui Program Kemitraan

dan Bina Lingkungan (PKBL)

untuk Meningkatkan Kinerja

UKM. RIPTEK. Volume 5,

No.11, 2011.

[14] Sri Susilo, 2010. Strategi meningkatkan daya saing umkm dalam menghadapi implementasi (1)CAFTA dan

MEA, Buetin Ekonomi, Volume 8 No. 2

[15] Suryana, Yuliawati. A.K, Rofaida.R. (2012).

Pengembangan Model

Ekonomi Kreatif Pedesaan

melalui Value Chain Strategy 
untuk Kelompok Usaha Kecil

Studi pada Industri Kerajinan

di Jawa Barat. Bandung: UPI

[16] Suryaningrum, Diah Hari.

2012.Knowledge Management and Performance of Samll and

Medium Entities in Indonesia.

International Journal of

Innovation and

Technology. Vol. 3 No 1.

February.

[17]Tambunan, Tulus. 2008.

Development of SME in

ASEnal oAN with Reference

to Indonesia and

Thailand.Chulalongkorn

Jounal of Economics, 20 (1)

April.

[18] Budi Tri Siswanto,

Pengembangan higher order

skills four cs (hos4c)

pendukung industri kreatif,

jurnal UNY, 2013.

[19] Dani Danuar Tri, 2013.

Pengembangan usaha mikro

kecil dan menengah (umkm)

berbasis ekonomi kreatif di

kota semarang, Skripsi,

Universitas Diponogoro, FEB,

Semarang,
[20] Ghassani, Nabila. Kemitraan

Pengembangan UMKM.

Kebijakan dan Manajemen

Publik. Vol.3, No.2, Mei-

Agustus 2015

[21] Putu Sudira, Dkk, 2014.

Pengembangan Model Lis 5 Cs

Pada Pendidikan Teknologi

dan Kejuruan. DIPA Pasca

Sarjana UNY.

[22] Rojewski. J.W (2009). A

Conceptual Framework for

Technical and Vocational

Education and Training. In R.

Maclean, D. Wilson, \& C.

Chinien (Eds.), International

Handbook of Education for the

Changing World of Work,

Bridging Academic and

Vocational Learning (pp. 19-

40). Germany: Springer.

[23] www.rohmadpertanianft-

peternakan.kediri.wordpress.co

m. Di akses pada tanggal 10

Desember 2017

[24] Huseini, Martani. Menata Ulang Strategi Pemasaran Indonesia.

Jurnal Reformasi Ekonomi.

Volume 1 No $1 \mathrm{Mei}$ 